Rafał Michalski

Uniwersytet Mikołaja Kopernika, Toruń, Polska

ORCID: 0000-0002-9587-5074

e- mail: metasis@umk.pl

\title{
Gra żałości - alegoria w barokowym dramacie żałobnym
}

DOI: http://dx.doi.org/10.12775/RF.2019.042

\section{Wstęp}

Prezentowany artykuł stanowi kontynuację mojego tekstu Melancholia $i$ katastrofa $w$ barokowym dramacie żałobnym ${ }^{1}$. Omówiłem w nim Benjaminowskie ujęcie melancholii w kontekście psychoanalizy i koncepcji suwerena Carla Schmitta. Pokazałem tam, że Benjamin podobnie jak autor Teologii politycznej tropi symptomy procesu sekularyzacji teologii, ale nie tyle w dziedzinie polityki i prawa, lecz w sferze estetycznej. Barokowa poetyka dramatu żałobnego stanowi dla niego reprezentatywny przykład początkowej fazy tego procesu. Podmiot sceniczny przeżywa w dramacie żałobnym rozmaite patologiczne objawy spowodowane napięciem między czyhającą zewsząd katastrofą a "cudownymi" (w sensie Schmittiańskim) mocami absolutnej suwerenności, która nieudolnie próbuje zapanować nad stanem kryzysu. W większości przypadków najważniejsze dramatis personae doświadczają nieuchronnej klęski, jednak na scenie dramatu zdarzają się również przebłyski kruchej nadziei, momenty nagłego skoku ku ocaleniu, w których ujawnia się ukryta głębia alegoryzującej świat melancholii. Co najważniejsze, zbawienie podmiotowości nie dokonuje się tutaj, zdaniem Benjamina, za pośrednictwem "cudu" obdarzającego jednostkę absolutną suwerennością, lecz

1 Rafał Michalski, „Melancholia i katastrofa w barokowym dramacie żałobnym”, Ruch Filozoficzny 2 (2019): 45-66. 
na mocy dialektycznego ruchu, w którym podmiotowość melancholijnie „zanurza się" w świat rzeczy opróżnionych z obiektywnego sensu, a zarazem - w tym właśnie akcie powrotu do stanu Stworzenia (= nagiego życia) - odnajduje ona iskrę mesjańskiej nadziei.

Barokowa żałość (Trauer) nie odnosi się wyłącznie do stanu psychologicznego, ale odsyła również do natury samej filozofii; ujawnia mechanizmy tworzące estetyczną konstrukcję dramatu, a ponadto określa metafizyczny obraz świata charakterystyczny dla XVIII wieku.

Odnosząc się do spekulacji psychoanalitycznych, pokazałem, że barokowa żałość w ujęciu Benjamina łączy w sobie momenty Freudowskiej melancholii (odczucie pustki wewnętrznej) i żałoby (doświadczenie pustki świata). Według Freuda melancholik i żałobnik stoją przed tą samą alternatywą: być lojalnym wobec rzeczywistości albo wobec utraconego obiektu. Pierwszy wariant wybiera żałobnik, drugi zaś melancholik. Praca żałoby polega w pewnym sensie na ponownym symbolicznym uśmierceniu tego, co już jest nieżywe dla żałobnika (utracony obiekt). Dopiero dzięki temu aktowi destrukcji podmiot może uwolnić się od widma przeszłości i powrócić do życia. Natomiast melancholik internalizuje obiekt, który staje się niejako jego własnym obcym ciałem, które próbuje upokorzyć, ale od którego nie potrafi się uwolnić. Pomimo wewnętrznego antagonizmu i spowodowanego nim cierpienia melancholik porzuca świat i pozostaje wierny utraconemu obiektowi. To jest główny powód, dla którego Freud uznaje melancholię za formę patologii, żałobę zaś za przejaw zdrowej postawy psychicznej. Benjamin widzi ten problem inaczej. Patologiczne jest dla niego porzucenie utraconego obiektu, ponieważ stanowi ono formę zdrady tego, co najcenniejsze dla podmiotu. W żałości nie chodzi bowiem o opanowanie straty, o pogodzenie się z nią lecz o głęboką artykulację śladów pozostawionych przez utracony obiekt. Ta wierność wobec utraconego obiektu, nieustanne zmaganie się z jego widmową obecnością staje się naczelnym etycznym imperatywem Benjaminowskiego melancholika. Obrana przez niego droga obciążona jest jednak potrójnym ryzkiem, które uwidoczniają postaci: męczennika, który pogrąża się we wzniosłej autodestrukcji, tyrana ulegającego iluzji omnipotencji, który z powodu niezdolności do podejmowania decyzji wchodzi ostatecznie w rolę męczennika, oraz ducha-zjawy, który jako widmowy ślad po „nieumarłej” przeszłości nie jest w stanie przekroczyć progu prowadzącego do wyższego świata, ponieważ utyka w fantazmatycznej strefie granicznej między życiem a śmiercią

Wszystkie trzy figury zmagające się ze stanem kryzysu ponoszą ostatecznie klęskę. Silnie uwypuklona w barokowym dramacie postać tyrana ukazuje konsekwencje, jakie mogą płynąć z praktycznej realizacji idei suwerenności Schmitta. Barokowy męczennik okazuje się karykaturą średniowiecznego świętego, a duch-zjawa symbolizuje zamknięcie traumatycznej przeszłości w kręgu nieskończonej repetycji. 
Wyzwalający, mesjański moment rozpoznaje Benjamin wyłącznie w postaci alegoryka, a szerzej - w alegoryczności języka dramatu żałobnego. To stanowi o osobliwości jego interpretacji. Iskrę nadziei w upadającym świecie da się bowiem odnaleźć, jego zdaniem, jedynie w alegoryzującym świat języku melancholika-filozofa. To on właśnie praktykuje widzenie świata jako maski kryjącej w sobie rozproszone fragmenty znaczenia, które usiłuje następnie ułożyć w znaczące konfiguracje i rozszyfrować2. Przepełniony żałością alegoryk stara się ożywić opróżniony z sensu świat rzeczy i własną duszę w inny sposób, niż czyni to Freudowski żałobnik. Barokowa żałość ucieleśniona w jego praktyce ożywia świat nie dzięki akceptacji utraty obiektu, ale dzięki nieustannemu przywoływaniu go. Alegoryk inaczej również niż Freudowski melancholik nie popada w autodestrukcyjne samooskarżenia, lecz próbuje opanować wewnętrzną pustkę $\mathrm{w}$ akcie odszyfrowania nieczytelnych śladów pozostawionych przez utracony i nieznany obiekt.

Jak należałoby w tym kontekście rozumieć rolę alegorii? Jak alegoria w swoim wymiarze figuratywnym i językowym może stać się narzędziem wskrzeszania mesjańskiej nadziei na urzeczywistnienie niezrealizowanych roszczeń przeszłości, które zgłasza utracony, choć paradoksalnie obecny w widmowej postaci obiekt? Czym właściwie jest ten obiekt? Pytania te narzucają się w perspektywie odczytania wykładni Benjamina przez pryzmat kategorii psychoanalitycznych. Nie jest to bynajmniej jedyna ani z pewnością najtrafniejsza perspektywa interpretacyjna. Jednakże częściowo nawiązuję do niej z zamiarem dokonania eksperymentu myślowego, w którym spróbuję skonkretyzować mgliste, teologiczne przesłanki i konkluzje dzieła Benjamina. Autor Źródła dramatu żałobnego w Niemczech w swoich analizach i meta-analizach splata ze sobą wątki krytycznoliterackie, estetyczne, historiozoficzne i teologiczne, nie stroniąc od motywów psychologicznych. Opisywane przez niego psychofizyczne symptomy, a nawet sensomotoryczne reakcje bohaterów dramatu żałobnego odtwarzają bezwiednie wstrząsy zachodzące na planie historycznym. Benjamin zakłada bowiem, że zarówno jednostkowa, jak i kolektywna historia oraz pamięć są analogiczne w swojej strukturze. Dlatego opisuje on Trauerspiel jako monadyczny obraz, który w skróconej formie przedstawia wizję całości barokowego uniwersum ${ }^{3}$.

W artykule zawężę interpretację dzieła Benjamina do wymiaru psychologicznego, świadomie uchylając wyrażaną przez niego nieufność wobec psychologizujących wykładni tekstów literackich. Nie będę

2 Por. tegoż, Antropologia mimesis. Studium myśli Waltera Benjamina i Theodora W. Adorna (Zła Wieś: Wydawnictwo Rolewski, 2008).

${ }^{3}$ Podobne założenie znajdujemy również u późnego Freuda poszukującego strukturalnych analogii między wymiarem psychologii jednostkowej i psychologii zbiorowości. 
jednak próbował wtłoczyć jego teoretycznej konstrukcji w ramy pojęciowe dyskursu psychoanalizy, lecz postaram się ukazać interesujące implikacje natury psychofilozoficznej związane z ideą podmiotowości alegorycznej, jaka wyłania się z jego rozważań nad istotą dramatu żałobnego. Nawiązania do psychoanalizy będą pełnić wyłącznie funkcję heurystyczną.

\section{W poszukiwaniu utraconego obiektu żałości}

Model podmiotu, jaki wyłania się z analizy dramatu żałobnego, cechuje niestabilność, brak trwałych podstaw, które wcześniej zapewniały metafizyczne filary chrześcijaństwa. Barokowy podmiot przepełniony jest ambiwalentnym stanem beznadziejnej żałości i frenetycznej gry. Do tej ambiwalencji nawiązuje już sama nazwa gatunku - w języku niemieckim das Trauerspiel, czyli gra żałobnego smutku. Pojęcie żałobnego smutku wskazuje, z jednej strony, na doświadczenie utraty obiektu nadającego spójność podmiotowi oraz sens zewnętrznej rzeczywistości, a tym samym na doświadczenie tęsknoty za tym obiektem, a z drugiej strony - opisuje dążenie do zatuszowania wszechogarniającego horror vacui za pośrednictwem arbitralnej gry znakami, którą stanowi kompulsywna alegoryzująca wszystko semioza. Jak w tym kontekście należałoby rozumieć pojęcie obiektu? Zaproponowana przeze mnie interpretacja żałości nawiązuje do psychoanalizy Freuda, który schematycznie sprowadza mnogość możliwych, utraconych obiektów do jednego fundamentalnego, jakim jest w jego spekulatywnej koncepcji matka. Bliższa ujęciu Benjamina wydaje się Judith Butler, która podobnie jak on uznaje pracę żałoby za formę zdrady obiektu i stawia na melancholię, która pozostaje mu wierna, chociaż nie potrafi go sobie uświadomić.

Pomijając polityczne implikacje Butlerowskiej wykładni melancho$\mathrm{lii}^{4}$, zatrzymam się na jej interpretacji pojęcia utraconego obiektu, aby w następnym kroku wykorzystać ją w kontekście rozprawy Benjamina.

Butler zaczyna swoje rozważania nad naturą melancholii od uwagi, że zakłada ona gotowość podmiotu do poddania się wewnętrznej przemianie. Ta uwaga wydaje się na pierwszy rzut oka paradoksalna, zważywszy na to, że melancholijną dolegliwość cechuje utrata chęci działania i obniżenie witalności cierpiącego. Autorka wyjaśnia jednak, że otwartość na transformację nie jest w tym przypadku efektem zamierzonego planu, ale polega na odczuciu bliżej nieokreślonej konieczności. To jakby odczucie niezgłębialnego, imperatywnego głosu, który nie wiadomo skąd dochodzi, ale domaga się wysłuchania. Według Butler

${ }^{4}$ Judith Butler, „Violence, mourning, politics”, w: tejże, Precarious life. The powers of mourning and violence (London-New York: Verso, 2004), 19-49. 
utracony obiekt nie oznacza konkretnej utraconej osoby, przedmiotu, miejsca, lecz coś, co stało się naszą integralną częścią jako skutek relacji z nimi. To coś (utracony obiekt) nie jest więc ani cechą obiektu, ani podmiotu odczuwającego stratę, lecz wyłania się jako pozostałość po wzajemnych emocjonalnych powiązaniach, która nie została uświadomiona przez melancholijny podmiot, dlatego nie potrafi on wyartykułować swojej straty za pośrednictwem języka, a nawet nie zdaje sobie sprawy z tego, co stracił. Niezwerbalizowane i nieuświadomione skutki wzajemnych powiązań tworzą więc wewnątrz melancholijnej podmiotowości nieprzeniknione, niezrozumiałe i nienazywalne residuum przesycone emocjonalną energią. Według Butler melancholia wbrew pozorom nie prywatyzuje podmiotu, nie zamyka go w subiektywnej przestrzeni cierpienia, wręcz przeciwnie - stanowi ona bolesne świadectwo tego, że Ja powstaje w wyniku dynamicznego zanurzenia w sieć wspólnotowych relacji. Melancholia może więc paradoksalnie otworzyć okno ludzkiej monady na nieprzejrzyste przestrzenie społecznego wymiaru w niej samej, może więc pomóc uświadomić jej, że swoją kruchą autonomię zawdzięcza nie tyle sobie, co innym, którzy świadomie lub bezwiednie przyczynili się do jej uformowania. Wychodząc od tego spostrzeżenia, Butler próbuje wykazać, że melancholijne doświadczenie daje szansę rozwinięcia głębszego poczucia wspólnotowości i pobudzenia jednostki do politycznej partycypacji w życiu społecznym. Naszą rekonstrukcję zatrzymamy w tym miejscu, ponieważ dalsze analizy autorki oddalają się od głównej linii wywodów artykułu. Do rozważań Benjamina odniesiemy jedynie jej intuicję na temat natury utraconego obiektu w stanie melancholii, wskazując najważniejsze różnice i podobieństwa.

Autor Źródła dramatu żałobnego w Niemczech ${ }^{5}$ unika, jak już wspomniano, psychologizującej interpretacji tekstów literackich. Żałość to nie tyle wewnętrzny stan podmiotu, lecz w pewnym sensie obiektywny nastrój, który go ogarnia. Obiektywność oznacza tutaj historyczność, a ściślej przyrododzieje - czas pozbawiony linearności, który przybiera postać repetytywnych, bezcelowych cykli prowadzących ku katastrofie. W żałości spotyka się więc niejako obiektywny ruch dziejów ujawnionych na scenie dworskich intryg i walki o władzę z subiektywną, alegoryczną wizją melancholika. Dzieje uwewnętrzniają się w melancholijnym podmiocie, którego imaginarium jedynie odzwierciedla to, co zostało bezwiednie umieszczone w jego wnętrzu - popękane, opróżnione z sensu uniwersum barokowego świata. Utracony obiekt oznaczałby w tym kontekście nie tyle ślad wytworzony przez relacje międzyludzkie, lecz efekt oddziaływania sfragmentaryzowanej, nieciągłej przyrodohistorii. Dlatego nieuświadomione residuum we wnętrzu podmiotu ża-

${ }^{5}$ Walter Benjamin, Źródło dramatu żałobnego w Niemczech, przeł. A. Kopacki (Warszawa: Wydawnictwo Sic!, 2013). 
łości nie skrywa w sobie pozytywnego potencjału więzi społecznych, jak u Butler, lecz kształtuje się raczej jako vacuum niespełnionych roszczeń przeszłości, których nie mogą zrealizować przyrododzieje. Najgłębszy wymiar podmiotowości, do którego może dotrzeć alegoryczna kontemplacja, stanowi arbitralnie skonstruowana mozaika subiektywnych odłamków przyrododziejów, pod którą skrywa się pragnienie restytucji rajskiego języka imion. Pragnienie to jest niejako awersem grzechu pierworodnego, który odciął ludzkość od kompletnego języka Adama. Jest ono puste, ponieważ jego przedmiot nie tylko nie istnieje, ale nie jest nawet wyobrażalny. $Z$ drugiej strony jest ono pleromatyczne (nabrzmiałe pełnią), ponieważ kumuluje się w nim, a następnie przekształca wyparta energia traumatycznych cierpień, jakich doznał podmiot w uwewnętrznionym uniwersum przyrododziejów. Kontemplacja alegoryka odsłania bowiem nie tylko obiektywne katastrofy, lecz przede wszystkim jego własne wewnętrzne wstrząsy. W istocie historia rozbija podmiot w chwili, gdy staje się jego integralną częścia, a nie wtedy, gdy działa na niego jako zewnętrzny wpływ, któremu można zawsze stawić opór (choćby w postaci tragicznej śmierci). Dzieje wrzynają się w podmiot, kształtują jego język, myśli, imaginarium, a niekiedy z impetem niszczą go, pozostawiając pod skorupami dostępnego mu języka pokłady niewyartykułowanego cierpienia. Cierpienie nieprzechwycone przez język może wywołać jego jałową żałość, ale może też przekształcić się w intensywne pragnienie wyzwolenia. Wydaje się, że odesłanie Benjamina do mitu rajskiego języka, który interpretujemy jako alegoryczne przedstawienie paradoksu utraconego obiektu, jest o tyle trafne, że przenosi utracony obiekt pragnienia z poziomu wyobrażeniowego na płaszczyznę języka, którego jeszcze nie ma. Mit rajskich imion przekształca się w dialektyce alegorii i nieustanie wymykającego się znaczenia w utopijna, zwróconą ku przyszłości nadzieję na ocalenie.

Butler podkreśla moc pozytywnych więzi, których ślad pozostawiony $\mathrm{w}$ melancholijnym podmiocie pozwala mu uświadomić sobie swoją ukrytą wspólnotową naturę. Benjaminowski podmiot żałości uwewnętrznia natomiast rozpad historii i erozję wspólnotowości. Oddając się ostentacyjnej alegorezie, przekształca się w tubę katastroficznej przyrodohistorii. Swiat Stworzenia jest upadły, przyrododzieje tracą celowość i mortyfikują świat naturalny, a świadczą o tym wszechobecne w dramacie żałobnym rekwizyty: czaszki, szkielety, motywy cmentarne, przedstawienia ruin.

Wykładnia Butler wskazuje na polityczny potencjał melancholii, zamykając ją w immanencji życia społecznego. Benjaminowska interpretacja lokuje $\mathrm{z}$ kolei sens żałości gdzie indziej, nie tyle w pojednaniu ze światem, lecz w gnostyckim skoku ku transcendencji. Wyjście ze stanu upadku możliwe jest zatem w wyniku interwencji cudu. Konkluzja rozprawy Benjamina rozczarowuje. Trafna krytyka Schmittiańskiego pojęcia 
cudu władzy suwerennej sama przekształca się ostatecznie w apologię mistycznej iluminacji, która ocala melancholika bez jego udziału. Interesująca krytyczna perspektywa odsłaniająca pierwsze zarysy nowoczesnego, a wręcz późnonowoczesnego modelu podmiotu w uniwersum dramatu żałobnego ustępuje motywowi gnostyckiej ucieczki ze świata Stworzenia ku niewyrażalnej prawdzie. Jeśli jednak zinterpretujemy cud jako samoczynną transformację wypartego cierpienia w nadzieję na ocalenie, cała konstrukcja Benjamina nabierze psychologicznego prawdopodobieństwa. Zanim przejdziemy do tej wykładni, przeanalizujmy samą koncepcję alegoryczności zawartą w rozprawie Benjamina.

\section{Alegoria i symbol}

Najbardziej rozpoznawalnym wątkiem omawianej rozprawy jest krytyka ugruntowanej w klasycznej estetyce strategii polegającej na dyskredytowaniu alegorii do poziomu całkowicie arbitralnego, retorycznego środka, który jedynie ilustruje pojęcia ogólne. Benjamin oparł swoją próbę rehabilitacji alegorii na założeniu, że procesy historyczne odzwierciedlają się na płaszczyźnie języka w odpowiadających im środkach wyra$\mathrm{zu}^{6}$. Jak przystało na gnostyka, potraktował tradycyjnie przeciwstawianą tej figurze i lokowaną wyżej w hierarchii doniosłości kategorię symbolu jako formę nieudanej symulacji głębi sensu w świecie, który sensu jest pozbawiony. Ściślej, uznał klasycystyczne i romantyczne ujęcia symbolu za nieuzasadnioną uzurpację opartą na transpozycji źródłowego, czyli teologicznego, znaczenia tego pojęcia do dziedziny estetycznej, gdzie zaczęto pojmować go jako jedność zjawiska i idei w sferze zmysłowej.

Do tego nadużycia dochodzi bowiem tam, i to wszędzie tam, gdzie manifestację jakiejś idei w dziele sztuki traktuje się jako symbol. Jedność przedmiotu zmysłowego i nadzmysłowego, paradoksalność symbolu teologicznego zostaje wypaczona: przeobraża się $\mathrm{w}$ relację zjawiska $\mathrm{i}$ istoty. [...] To, co piękne, jako twór symboliczny ma bezboleśnie przejść w to, co boskie ${ }^{7}$.

W teologicznym ujęciu symbolu obydwa tworzące go bieguny materialności znaku i idealności znaczenia pozostają względem siebie zewnętrzne. Duchowy, pneumatyczny sens ujawnia się tutaj wprawdzie na płaszczyźnie symbolizującego znaku, jednak ostatecznie, z uwagi na swoją niewyrażalność, zaświadcza o niemożliwości przedstawienia. Nie dochodzi więc w nim do zespolenia obydwu wymiarów, jak sugerują

6 Tamże, 86.

7 Tamże, 208. 
krytykowane przez Benjamina estetyczne teorie. Symbol jako fizyczny znak szczególny może jedynie pośrednio odsyłać do transcendentnego, nieprzedstawialnego z istoty znaczenia. Symboliczne uobecnienie sensu męki Chrystusa w misteryjnych rzeźbach nie stanowi jej ucieleśnienia, lecz wyznacza naznaczoną aurą świętości przestrzeń, w której może dokonać się cud przemiany duchowej uczestnika misterium. Symbol teologiczny pozostaje zawsze znakiem przełamanym ${ }^{8}$, w którym niemożliwa jest bezpośrednia prezentacja obiektu symbolizowanego. W estetycznych koncepcjach klasycyzmu i romantyzmu symbol może natomiast osiągnąć momentalną pełnię, całkowite zjednoczenie pierwiastka idealnego i zmysłowego. Dla Benjamina takie ujęcie nabiera cech mitycznych, ponieważ łudzi wizją całości, pozorem pełnego pojednania tego, co ogólne, z tym, co jednostkowe. Mówiąc po heideggerowsku, sekularyzacja teologicznego symbolu prowadzi do mitologicznej metafizyki obecności, która zgłasza fałszywe roszczenie do stopienia transcendencji z immanencją. Dotyczy to również symboli religijnych, które analogicznie próbują ewokować organiczną jedność zmysłowego znaku i duchowej treści, przeobrażając się nieuchronnie w zwodniczy obiekt idolatrii.

Benjamin nie rozwija rozważań na temat symbolu teologicznego, dlatego nie można mieć pewności, jakie funkcje przypisywał mu w swojej wizji historiozoficznej, jednak w kontekście rozprawy o dramacie żałobnym funkcjonuje on (symbol teologiczny) jako punkt odniesienia dla krytyki ujęć klasycystycznych i romantycznych. Z całą pewnością Benjamin wskazuje jednak, że za parawanem estetycznej frazeologii, która opisuje symboliczną sztukę, dochodzi do ukrytej transmisji mitu. Mit polega na mistyfikacji, na tworzeniu zwodniczej, ahistorycznej narracji o „prawdziwym”, wiecznie takim samym, głębokim wymiarze rzeczywistości. Podobnie estetyczny symbol unieważnia czas, ponieważ znaczone zostaje w nim bezpośrednio uobecnione przez znaczące. Tak pojęty symbol zakłada ponadto szczelną tożsamość podmiotu, który w estetycznym doświadczeniu symbolicznej sztuki zamienia się $\mathrm{w}$ „piękną duszę". Schillerowska idea wewnętrznego kształtowania jednostki, która poprzez estetyczne wychowanie dojrzewa do rozumnej moralności, stanowi dobry przykład mitologicznej koncepcji autonomii podmiotu. Benjamin gnostyk nie wierzy w ideę suwerennej podmiotowości, która dyktuje światu prawa, pozostaje niezależna od zewnętrznych wpływów i hermetycznie odizolowana od niewysublimowanych afektów. Bliższa jest mu natomiast idea barokowej alegorezy, która mimowolnie niszczy iluzoryczną zasłonę piękna i trafnie odzwierciedla strukturę historycznej rzeczywistości. Alegoryzująca wizja odsłania bowiem pokawałkowany, ograbiony z celowości świat, w którym ludzkie doświadczenie

8 Por. Adam Lipszyc, Sprawiedliwość na końcu języka (Kraków: Universitas, 2012), 114-136. 
traci bezpośrednie odniesienie do absolutu, a język gubi się $w$ frenetycznej samowoli, nie docierając do stałego sensu. Gdy historyczna rzeczywistość zmierza ku katastrofie, roszczenie do piękna promowane przez symboliczne dzieła sztuki staje się chimeryczną formą automistyfikacji.

W trzeciej części rozprawy Benjamin poddaje krytyce różne koncepcje dyskredytujące alegorię na rzecz symbolu i zatrzymuje się dłużej przy ujęciu Friedricha Creuzera, niemieckiego filologa i badacza mitów epoki romantyzmu. Dla Benjamina ważne okazuje się dokonane przez Creuzera porównanie temporalnego aspektu obydwu figur. Istotną cechą symbolu, według tej koncepcji, jest „momentalna totalność”, alegorii zaś - „postęp w szeregu momentów" ${ }^{\prime 9}$. W symbolu znaczone i znaczące występują jednocześnie w punktowej epifanii, natomiast alegoria sygnalizuje ich nieprzystawalność, rozsuwającą się między nimi lukę, którą bezskutecznie próbuje wypełnić szeregiem kolejnych arbitralnych znaków. Creuzer interpretuje repetytywność, nieciągłość i arbitralność alegorii jako skutek nieskończonej progresji, jako rezultat nieustannych przesunięć znaczenia, co jego zdaniem powoduje, że należy ją uznać za pochodną mitycznej opowieści. Benjamin koryguje to ujęcie, wskazując, że nie tyle alegoria, lecz właśnie symbol czerpie z „niezgłębialnego źródła" mitu, ponieważ podtrzymuje iluzję sacrum uobecnionego w wymiarze immanencji. Natomiast alegoria dzięki swojemu sekwencyjnemu charakterowi doskonale odzwierciedla nieciągłą naturę historycznej rzeczywistości. Ponadto zawarta $\mathrm{w}$ alegorii tendencja do urzeczowiania wszystkiego (tj. zamieniania wszelkich obiektów w nieskończoną sekwencję znaczących sygnatur) otwiera przestrzeń dla krytyki, która może rozsadzić wyobrażeniową fasadę symbolicznego mitu snującego fałszywą wizję jedności immanencji i transcendencji. Konieczność oraz bezpośredniość znamionująca symbol wikłają go w sieć tajemnych korespondencji i sił natury, które jak mityczne fatum wywierają swój demoniczny wpływ na ludzkie życie. Według Benjamina estetyczny symbol stanowi więc, wbrew klasycystycznym i romantycznym wykładniom, pozostałość, a wręcz medium mitycznej przemocy, a nie quasi-mistyczne naczynie wieczności. Aby lepiej zrozumieć związek symbolicznej iluzji z mitem, warto przyjrzeć się analogicznej relacji tragicznego bohatera z mitycznym fatum.

We wcześniejszym eseju Los $i$ charakter Benjamin stwierdza, że ,[...] w tragedii demoniczny los zostaje przełamany. Nie jest jednak tak, że związek winy i pokuty [...] zostaje rozwikłany i zastąpiony przez czystość człowieka oczyszczonego z winy i pojednanego z czystym Bogiem. W tragedii pogański człowiek uświadamia sobie sobie raczej, że jest lepszy od swych bogów, ale ta wiedza odbiera mu mowę i zostaje

9 Benjamin, Źródło dramatu żałobnego, 215. 
stłumiona"10. Śmierć tragicznego podmiotu nosi nieuchronnie znamiona ironii. $Z$ jednej strony jest ona jedynym sposobem przezwyciężenia mitycznego fatum, tragicznym właśnie świadectwem wolności człowieka, który dojrzał „wyższy ład moralny”, jednakże, z drugiej strony, niemota i fizyczne unicestwienie nie pozwalają mu ustanowić tego ładu i potwierdzają jego ostateczną uległość wobec losu zawiadywanego przez transcendentnych bogów (wykreowanych przez mit). Podobnie bezpośredniość i spontaniczność estetycznego symbolu okazują się ekspresją podmiotowości podporządkowanej konieczności (tym razem reprezentowanej przez siły natury). Geniusz estetyczny tworzący symbol ulega mitogennym, twórczym mocom „nagiego życia”, które - jak pisze Benjamin - jest właściwym podmiotem mitycznego losu.

Różnie artykułowane koncepcje geniuszu jako bezpośredniego wyrazu niezbadanych sił natury stanowią przedłużenie mitycznej narracji ograbiającej człowieka z indywidualności i decyzyjności. Podmiotowość symboliczna zostaje tutaj niejako przekupiona przez mit, który kusi ją pirotechnicznymi rozbłyskami ulotnej chwili natchnienia, nad którymi nie ma ona żadnej kontroli. Symbol odsyła więc do mitu i tragicznej ironii, ta zaś według Benjamina leży u podstaw wzniosłości estetycznej. Wzniosły podmiot doświadcza bowiem przebłysku wolności w obliczu grozy istnienia, który przemija równie szybko, jak się pojawił, i w ten sposób ostatecznie przypieczętowuje niemoc Ja i jego uwikłanie w mit.

We wczesnej spirytualistycznej koncepcji Benjamina, do której nawiązuje omawiane dzieło, natura podobnie jak ludzki język, który ją nazywa, uległa degradacji po wypędzeniu Adama z raju i katastrofie wieży Babel. Naturze brakuje bowiem rajskiego języka imion, który wyrażałby jej duchową istotę, dlatego pogrąża się w smutku zagłuszanym gadaniną pomieszanych języków ${ }^{11}$. Mit stanowi efekt korupcji czystego języka i fałszywą próbę jego zastąpienia. Alegoria zakłada więc smutek natury, jej niemotę oraz żałość podmiotu ogarniętego taedium vitae.

\section{Alegoreza}

Alegoryk zaczyna postrzegać świat opróżniony z sensu i nie widzi już naturalnego (mitycznego) powiązania między słowami a rzeczami. To prowadzi do dewaluacji świata. Podmiot zostaje zdany na samego siebie, traci zakorzenienie we wspólnocie, zrywa społeczne związki oparte na mitycznych regułach obyczajowości. Dewaluacja, skrajne odczarowanie

10 Tegoż, Los i charakter, w: tegoż, Konstelacje, przeł. A. Lipszyc, A. Wołkowicz (Kraków: Wydawnictwo Uniwersytetu Jagiellońskiego, 2012), 64.

11 Tegoż, O języku wogóle i o języku człowieka, w: tegoż, Konstelacje, przeł. A. Lipszyc, A. Wołkowicz (Kraków: Wydawnictwo Uniwersytetu Jagiellońskiego, 2012), 1-18. 
świata oczyszczonego ze znaków boskości stanowi początkowe stadium fenomenologii podmiotowości barokowego dramatu żałobnego. Rezultatem zmiany optyki alegoryka jest zaś fragmentaryzacja, pokawałkowanie rzeczywistości, która jawi się mu jako rumowisko pozbawionych suwerennego sensu ułamków istnienia. To z kolei uruchamia proces alegorezy - konstruowania subiektywnych, arbitralnych znaczeń. Alegoria staje się tym samym nieodłączną modalnością melancholii. Melancholik może obyć się bez alegorycznej kreatywności, jednak alegoryk potrzebuje melancholijnej dyspozycji jako warunku koniecznego dla swoich operacji.

Aura śmierci spowijająca barokowe uniwersum kłóci się z symboliczną wizją śmierci jako spełnienia boskiego fatum. Mortyfkacja rzeczy i ich sensu nabiera "postmitycznego" sensu, ponieważ odsłania skrajnie opozycyjną wobec symbolicznej apoteozy przemijalność wszystkiego i podporządkowanie podmiotowości przyrododziejom.

Centralnym problemem alegorii jest zatem u Benjamina agonia, rozpad języka, podmiotu i jedności świata. Śmierć stanowi tutaj przeciwstawny biegun tego, do czego zmierza alegoryczna dialektyka, a mianowicie znaczenia (Bedeutung), które gubi się w nieokreśloności, $\mathrm{w}$ ambiwalentnym ruchu między potrzebą ocalenia a samowolnym wytwarzaniem nadmiaru znaków.

Tyle znaczenia, ile śmiertelności, ponieważ to śmierć najgłębiej wyżyna zębatą linię demarkacyjną między fizycznością a znaczeniem. Jeśli jednak natura jest od zawsze śmiertelna, to od zawsze jest alegoryczna. Znaczenie i śmierć tak jak są wytworami rozwoju historycznego, tak też przenikają się nawzajem jako zarodki w nieobjętym łaską stanie grzeszności stworzenia ${ }^{12}$.

Alegoryczna intencja wypełnia lukę między obrazem a znaczeniem obfitością arbitralnych znaków. Alegoryczny obraz w przeciwieństwie do symbolu nie przechodzi płynnie $\mathrm{w}$ dziedzinę boskości, lecz rozbija rzeczywistość na fragmenty, by móc naznaczyć je nowym znaczeniem.

Jeśli pod wpływem melancholijnego spojrzenia przedmiot staje się alegoryczny, jeśli melancholia sprawia, że uchodzi z niego życie, jeśli zostaje porzucony - martwy, ale jednak zabezpieczony na wieczność - to alegoryk ma go do swojej dyspozycji: przedmiot zdany na jego łaskę i niełaskę. To znaczy: od tej chwili jest on całkowicie niezdolny do emanowania znaczeniem czy sensem: znaczenia przysługują mu tyle, ile udzieli go alegoryk $^{13}$.

12 Tegoż, Źródło dramatu żałobnego, 218.

13 Tamże, 243. 
Przerwanie ciągłości pomiędzy znaczącym i znaczonym przybiera tutaj skrajną postać. Alegoryczny obraz bezpowrotnie oddzielony od znaczenia zaczyna funkcjonować jako fragment, odłamek rozbitego wewnętrznie logosu, a jednocześnie wyraża wzajemne przenikanie się natury i dziejów oraz ukształtowanego w nich podmiotu wyłącznie dzięki swojej formie, a nie znaczeniu. Konwencjonalność alegorii staje się tym samym paradoksalną formą ekspresji, odzwierciedleniem głębokiej struktury przyrododziejów. „Siedemnastowieczna alegoria nie jest konwencją wyrazu, lecz wyrazem konwencji"14.

Prawidłowość ta dotyczy przede wszystkim alegorii opanowanych „mechanizmem egzaltacji”, ponieważ to właśnie w nich najintensywniej dochodzi do głosu zasada przekształcenia - podstawowy schemat barokowej alegoryzacji świata. Arbitralność alegorii wyraża dominację człowieka nad pozbawioną obiektywnego sensu rzeczywistością, a z drugiej strony staje się doskonałym narzędziem do przeobrażenia jej w opalizujący znaczeniem tekst. „Wszystko, czego dotyka [alegoria] swoją midasową ręka, przeobraża się w coś znaczącego"15.

Aby przekształcić rozproszone obrazy rzeczywistości w znaczące treści, alegoryk musi najpierw zburzyć obowiązujący porządek sensu. „To, co leży wśród ruin jako odprysk, wielce znaczący fragment, ułomek: oto najszlachetniejsza materia twórczości barokowej" ${ }^{\prime 16}$. Dlatego też alegorie „[...] są tym w królestwie myśli, czym ruiny w świecie rzeczy"17.

Tak jak symbol wskazuje na organiczny związek świata i historii, tak alegoria staje się wyrazem rzeczywistości rozbitej na fragmenty. Dlatego idealną alegorią barokowej wizji dziejów okazuje się obraz ruiny. „Alegoryczna fizjonomia przyrododziejów w inscenizacji dramatu żałobnego uobecnia się rzeczywiście jako ruina"18. Ruina to zniszczona budowla, otwarta wewnętrzna przestrzeń, która przestaje służyć jakiemukolwiek celowi. Przyrododzieje jako zgliszcza po historii zbawienia prowadzą ku śmierci, każda próba ich usensownienia kończy się porażką, dlatego alegoryczna nadprodukcja obrazów i subiektywnych znaczeń pogłębia tylko linię demarkacyjną między śmiercią a znaczeniem. Benjamin ujmuje to następująco:

Podczas gdy w symbolu wraz z przebóstwieniem upadku ulotnie objawi się poddane transfiguracji oblicze natury w świetle zbawienia, $\mathrm{w}$ alegorii oczom patrzącego ukazuje się facies hippocratica historii jako zakrzepły pierwotny pejzaż. Historia wraz ze wszystkim, co od początku jej towarzyszy jako to, co niewczesne, związane z cierpieniem, chybione, odciska

\footnotetext{
14 Tamże, 230.

15 Tamże, 311.

16 Tamże, 235.

17 Tamże, 234.

18 Tamże.
} 
się na obliczu - nie w trupiej czaszce. I choć prawdą jest, że brak takiemu odwzorowaniu wszelkiej "symbolicznej” swobody wyrazu, wszelkiej klasycznej postaci, czegokolwiek ludzkiego w tej jednostkowej postaci, która jest najbardziej podległa naturze, wyraża się znacząco, jako zagadka, nie tylko natura ludzkiego bytowania, lecz także biograficzna dziejowość jednostki. To samo sedno patrzenia alegorycznego, barokowej, świeckiej ekspozycji historii jako męczeńskich dziejów świata; znaczenie mają tylko kolejne stacje rozpadu ${ }^{19}$.

Alegoreza odzwierciedla melancholijną wizję świata, w której wybujałość obrazów przemocy, klęski i rozpadu tworzy emblematyczną fizjonomię przeklętych dziejów natury i ludzkości. Zastygły, opróżniony z sensu świat postrzegany przez alegorystę jako maska śmierci staje się dla niego „zakrzepłym, pierwotnym pejzażem”, który zakłada uprzednie, skrajne wyobcowanie od bezpośredniości codziennego doświadczenia. W ten sposób tworzy się dialektyka przyrododziejów: zalegoryzowana natura przekształca się $\mathrm{w}$ kontinuum dziejowej katastrofy, w ruinę historycznych klęsk ujawniających uniwersalność śmierci, a historia zamienia się $\mathrm{w}$ widmo monotonnej repetycji, w obumierającą naturę.

Zdecydowane odrzucenie klasycznego ideału piękna odzwierciedlone na poziomie materialno-zmysłowym $\mathrm{w}$ motywie ruin odpowiada $\mathrm{w}$ warstwie formalnej dominacji alegorycznego przedstawienia nad reprezentacją symboliczną. Zeświecczony świat barokowego dramatu żałobnego nie mógł według Benjamina znaleźć innego sposobu wyrażenia swojej wizji dziejów. Wszelka sztuka tego okresu, chcąc nie chcąc, musiała zmagać się z przedstawieniem relacji człowieka do absolutu. Alegoria wskazywała fragmentaryczną naturę tej relacji w świecie, który sam został zredukowany do nieskończonego ciągu fragmentów pozbawionych obiektywnego sensu.

W interpretacji Benjamina można bez trudu dostrzec wpływ estetyki wczesnego Lukácsa, który w swojej Teorii powieści podobnie opisuje świat drugiej natury (= przyrododziejów u Benjamina):

Natomiast natura, ogołocona równocześnie i z życia własnego, odległego od wszelkiego sensu, i ze swej bogatej w sens symboliki, okazuje się tłem, dekoracją, akompaniamentem. Straciwszy swą niezawisłość, zmienia się w zmysłowo uchwytną projekcję jedynego, co istotne - wnętrza. [...] Nie idzie tu o naturę niema, dostępną zmysłom i niezawierającą sensu, jak pierwsza natura. Idzie o skamieniały, obcy i niestymulujący już wnętrza zbiór sensów, o kostnicę jakby, w której nagromadziły się martwe treści wewnętrzne ${ }^{20}$.

19 Tamże, 217-218.

${ }^{20}$ György Lukács, Teoria powieści, przeł. J. Goślicki (Warszawa: PIW, 1968), 56. 
Natura wystylizowana na potrzeby sceniczne dramatu żałobnego nie jest już symbolicznie reprezentowana przez pogodnych bogów olimpijskich, lecz przez "czaszkę" - alegorię śmiertelności i przemijalności, która bynajmniej nie ucieleśnia sobą rozpadu, a jedynie go re-prezentuje, domagając się dopełnienia z zewnątrz, ze strony alegoryka. Znaczenie alegorii czaszki, podobnie jak każdej innej barokowej alegorii, nie jest samowystarczalne ani oczywiste. Alegoryk jako absolutny suweren, „władca znaczeń", tworzy chaotyczny kosmos arbitralnych znaków, które odsyłają wyłącznie do jego demiurgicznej, skrajnie subiektywnej wyobraźni. Z poczuciem omnipotencji wyrywa ze świata fragmenty rzeczy, tworzy z nich arbitralne obrazy odarte $z$ naturalnego znaczenia, zamienia je w hieroglify i opatruje nowym znaczeniem. Jednakże obrazy te pozostają enigmatyczne, nieczytelne, przez co uwidaczniają kryzys znaczenia, stają się fragmentami układanki obrazkowej, która domaga się rozwiązania.

Obrazy w polu alegorycznej intuicji to ułomki, runy. Ich symboliczne piękno rozprasza się, gdyż trafia w nie promień Bożej uczoności. Totalność przestaje świecić fałszywym blaskiem. Bo gaśnie eidos, obumiera parabola, a kosmos w niej martwieje. Ostają się suche rebusy, które zapewniają możliwość wglądu - nawet temu, kto oddaje się najbardziej chaotycznym dociekaniom (dem verworrenen Grübler) ${ }^{21}$.

Melancholijna zaduma myśliciela (Grübler) nad fragmentami, które na zewnątrz arbitralnie odzwierciedlają stan jego subiektywnej żałości, uwalnia w nim potrzebę zmiany i uruchamia sensotwórczą alegorezę. Dzięki temu może on przełamać mit łudzący spójnością świata wokół niego i w nim samym. Destrukcja mitycznej totalności świata pomieszanych języków i ludzkiego cierpienia budzi w nim natomiast słabą, utopijną nadzieję na odzyskanie utraconego porządku rajskich imion i autentyczne pojednanie ze światem.

Przypadkowe, a jednak wybrane mocą arbitralnej decyzji alegoryka fragmenty rzeczywistości stają się dla niego nośnikiem paradoksalnej pamięci o raju. W teologicznej wykładni Benjamina człowiek dziedziczy bowiem nie tylko znamię grzechu pierworodnego, ale również mgliste przeczucie utraty rajskiego uniwersum, bezprzedmiotowe wspomnienie, które niejako odbija się od nieprzedstawialnego „rajskiego imienia” i zwraca ku przyszłości. Jego paradoksalny "obiekt” nie jest czymś zapomnianym, ponieważ nigdy nie był doświadczony, ale zapowiada się jako coś bliskiego, choć jeszcze nieistniejącego. Alegoryczność unaocznia wszechobecność tej pamięci. Nie wyzwalają jej bowiem jakieś szczególne, predestynowane do tego symbole. W istocie dowolny obraz,

${ }^{21}$ Benjamin, Źródło dramatu żałobnego, 232. 
fragment rzeczywistości może obudzić pragnienie restytucji utraconego świata. Ważny jest tutaj moment dojmującej żałości, która uruchamia akt alegorezy. Desperackie poszukiwanie utraconego obiektu prowadzi do zburzenia iluzji symbolicznej totalności, która pozoruje iluzję sensownego ładu. Dlatego alegorie odsyłające do przemijalności, śmierci, upadku stają się najlepszym katalizatorem tej anamnezy. Nie pozostawiają one złudzeń co do wartości upadłego uniwersum i ożywiają utopijną nadzieję na pojednanie poza dychotomiami poznania intelektualnego.

Jednakże pragnienie zdobycia wiedzy poza obszarem poznania okazuje się sprzecznościa, która rodzi lament i coraz bardziej rozpaczliwe, beznadziejne poszukiwania prowadzące melancholijnego alegoryka w przepaść własnej subiektywności. Wyrwane z kontekstu, opatrzone nowym znaczeniem, obrazowe fragmenty świata sugeruja że można z nich ułożyć nową mozaikę, która ukaże prawdziwy obraz pojednanego świata. $W$ tym bezustannym konstruowaniu całości z fragmentów chodziłoby o odkrycie właściwej struktury czy też konstelacji, jak pisze Benjamin. Nie poprzedza ona poszczególnych elementów ani nie jest czymś, co wyłania się później. Wiedzy o wzorcu tworzącym właściwy obraz nie da się wyprowadzić z wiedzy o elementach. Sam wzorzec nie jest również wytworem grającego fragmentami alegoryka, dlatego ponawiane przez niego bezskuteczne próby znalezienia całości paradoksalnie mogłyby upewnić go o bliskości nieobecnego Boga. Jednakże barokowa alegoria występująca w niemieckim dramacie żałobnym (w przeciwieństwie do dramatu hiszpańskiego) nie była w stanie dostrzec tej bliskości.

Katastroficzny Trauerspiel mnoży alegorie, skłaniając się do prymatu pisma i schematu świętego tekstu, a przez to do przedbarokowej maniery czytania natury jako księgi zawierającej moralne i religijne instrukcje. $\mathrm{W}$ tej tendencji uwidaczniają się wpływy renesansowej egzegezy antycznego archiwum przedstawień mitologicznych oraz średniowiecznych doktryn o grzeszności materii i transmutacji naturalnej egzystencji w tekst ludzkiej winy. Barokowa alegoreza łączy te wpływy i w efekcie otwiera perspektywę postrzegania ludzkiej natury jako synonimu przemijalności i winy. Najczystszym nośnikiem obydwu cech jest martwe ciało, dlatego centralną alegorią baroku stają się zwłoki. Martwe ciało naznaczone winą spoczywa na dnie alegorycznego upadku i przedstawia sobą dialektyczną relację między podmiotem żałości a jego przedmiotami.

Arbitralna alegoreza praktykowana przez melancholijny podmiot nie biegnie w nieskończoność, lecz napotyka swój kres w obrazie ludzkich zwłok, ponieważ wyczerpują się w nim możliwe permutacje znaczenia, jakie alegoryk narzuca obiektom, a sama alegoria traci swoją arbitralność. Alegoria i zwłoki odsyłają bowiem ostatecznie do tego samego znaczenia - winy i przemijalności będących skutkiem grzechu pierworodnego. Alegoria zwłok to niejako ostatnia stacja alegorycznych 
poszukiwań, na której zatrzymuje się aktywność podmiotu przenikniętego żałością. Podmiot dociera tutaj do kresu swoich intencji, jego zabsolutyzowana subiektywność dosłownie obumiera, doświadczając piekła upadłej natury.

\section{Pismo}

Jak już wspomniano, alegoria barokowa wyrażająca ontologiczny stan żałości na poziomie językowym nie była bynajmniej wynalazkiem XVIII wieku. Benjamin podkreśla jej ścisły związek z tradycją ezoteryzmu. Dla alegorycznej wyobraźni znaczenie jest niemal z definicji czymś tajemniczym, nabrzmiałym okultystycznym odesłaniami. Fascynacja fragmentem łączy się tutaj z ezoterycznym przekonaniem, że rozmaite dyskretne zjawiska świata naturalnego stanowią hieroglificzne, znaczące sygnatury. Ostatecznym celem alegorii jest zatem deszyfrowanie znaczeń ukrytych we fragmentach upadłego świata. W wykładni Benjamina alegorycznie ocalony sens nie ma jednak nic wspólnego z niejawnym hermetycznym porządkiem rzeczywistości, lecz dotyczy niewyartykułowanych dziejów cierpienia i wyobcowania przesłoniętych parawanem tradycyjnej historiografii.

Źródłem ezoterycznego aspektu alegorii była według niego renesansowa fascynacja egipskimi hieroglifami, które ówczesna mistyczna filozofia natury interpretowała jako archiwum okultystycznych doktryn. Renesansowi uczeni, podążając za hermeneutycznymi praktykami późnego antyku, próbowali wyczytywać z hieroglifów rozmaite metafizyczne znaczenia. Fonetyczne znaki przekształcali w znaki leksykalne, a te w obrazy-ikony, oderwane od historycznego znaczenia i coraz bardziej oddalone od naturalnego związku ze zmysłową rzeczywistością. Neoi pseudoantyczna alegoryzacja hieroglifów stapiała się wówczas z chrześcijańskim dydaktyzmem, z demonologią i astrologią. Wzorcowym przykładem takiej praktyki był dla Benjamina Marsilio Ficino, który odczytywał hieroglificzne znaki jako wizualne przedstawienia symbolizujące mistyczne jakości natury. Ta „hieratyczna ostentacja” alegorezy przekształciła się w baroku w "naturalną teologię pisma”. Alegoryczna stała się bowiem wówczas sama natura pojmowana jako zaszyfrowane pismo, uniwersum sekretnych run objawiające dziejową katastrofę.

Benjamin podkreśla, że w idei pisma tkwi dialektyka charakterystyczna również dla samej alegorii: napięcie między materialnością zna$\mathrm{ku}$ a fizyczną nieobecnością znaczenia. W barokowej alegorezie funkcję pisma przejmuje zmortyfikowana i sfragmentaryzowna natura, która odsyła do ukrytego, nieobecnego znaczenia. Alegoriami stają się tutaj wyrwane z organicznych kontekstów pojedyncze rzeczy lub ich fragmenty, które tworzą rodzaj pisma obrazkowego. Alegoria ukazująca 
obiekt nie odsyła jednak ani do tego obiektu, ani do jakichś jego symbolicznych prawzorów, ponieważ z definicji odrzuca ona naturalny, oparty na zasadzie podobieństwa związek między znaczącym a znaczonym. Arbitralność związku alegorii i jej znaczenia narzuca konieczność kontynuowania semiotycznych szeregów, tworzenia kolejnych przedstawień. Rozziew, nieusuwalna luka między obrazem a znaczeniem tworzy pustą przestrzeń, którą alegoreza wypełnia kolejnymi przedstawieniami. Żaden retoryczny zabieg nie jest w stanie przerzucić mostu nad tą przestrzenią. Wszelka referencja ponosi więc fiasko. Oczywiście nie ma tu również miejsca dla budowania symbolicznych połączeń między immanencją (znaku) a transcendencją (znaczenia) nawet w wymiarze czysto religijnym. Pozytywne średniowieczne symbole i elementy historii Zbawienia zamieniają się $\mathrm{w}$ dobie baroku w tekturowe atrapy, które nie opalizują już blaskiem świętości. Za Blumenbergiem moglibyśmy powiedzieć, że „ucieczka” późnośredniowiecznego Boga jako Deus absconditus w stan całkowitej niepoznawalności zamknęła przed człowiekiem wszelki dostęp do transcendencji ${ }^{22}$.

Benjamin łączy zamiłowanie barokowych dramatopisarzy do alegoryzacji z dokonującą się na ich oczach zmianą wizji dziejów. Imaginarium dramatu żałobnego daje bowiem wzorcowe świadectwo przekształcenia czasu chrześcijańskiej teleologii w zsekularyzowane przyrododzieje. Uniwersum przyrododziejów to lucyferyczny świat immanencji, upadku ducha w materię, ciągłości czasowej w przestrzenną rozciągłość. Panuje w nim stężały czas melancholii, który traci linearność i przybiera postać wiecznego powrotu tego samego. Dramat żałobny przedstawia losy bohaterów w alegorycznym skrócie, nie tworzą one żadnej ciągłości, lecz przekształcają się w zawrotną kombinatorykę heterogenicznych scen-obrazów. Główne postacie zaplątane w gęstą sieć dworskich intryg giną z ręki swoich podwładnych, a na ich miejscu pojawiają się inni, którzy kończą podobnie. Powtarzalne sekwencje obrazów, cykle melancholijnego przygnębienia i hedonistycznego szału rozbijają linearność biegu zdarzeń, która mogłaby wskazywać na jakikolwiek zewnętrzny cel. Mechaniczny, bezcelowy bieg akcji, jego repetytywność odzwierciedla nie tylko alegoryczne uprzestrzenienie dziejów, ale również całkowite uwikłanie ducha w materialność świata. Żadna z postaci nie potrafi bowiem podjąć suwerennej decyzji ani siłą własnej woli wydostać się z piekielnego kręgu immanencji. Ich działania pozbawione są autentycznej sprawczości; z powodu swojego automatyzmu upodobniają się do ruchów marionetek poruszanych niewidzialnym sznurkami złowieszczego fatum.

${ }^{22}$ Hans Blumenberg, Prawowitość epoki nowożytnej, przeł. T. Zatorski (Warszawa: PWN, 2019). 
Alegoryzacja dramatu żałobnego przejawia się również w nieobecności żywego dialogu. Słowa wypowiadane na scenie przywodzą na myśl stereotypowe klisze, formuły językowe, które stanowią niejako odrębna, urzeczowioną część przedstawienia. Benjamin porównuje je do tasiemek z napisami wydobywającymi się ust postaci na starych obrazach. Wyobcowana mowa zamienia się w swoisty rodzaj pisma, w zastygający w samym akcie wypowiedzi flatus vocis.

Alegoria jako pismo, a dosłownie jako uśmiercona i rozpostarta $\mathrm{w}$ dwuwymiarowej przestrzeni mowa wyraża na poziomie językowym mechanizm funkcjonowania przyrododziejów, natomiast melancholijny alegoryk staje się estetyczno-transcendentalnym podmiotem dramatu żałobnego.

\section{Obietnice Szatana}

Barokowy alegoryk nie jest bohaterem tragicznym, który przełamuje istniejące status quo w imię innego porządku wartości. Wręcz przeciwnie, jego wybujała kreatywność powiela jedynie prawidła rządzące światem, który przyprawia go o żałość. Nie składa on w ofierze swojego życia, lecz ostentacyjnie celebruje własną niemoc, własne zanikanie w potoku arbitralnych obrazów. Im bardziej energicznie ponawia swoje daremne próby znalezienia nadziei na zbawienie, tym mocniej przeżywa jej nieobecność, tym głębiej grzęźnie w bezdusznej materii przyrododziejów. Jego twórcza subiektywność prowadzi go ostatecznie do utraty autonomii i zerwania związku ze światem, z którego ulatnia się obiektywny sens. Jego klęska nabiera zaś znamion tragikomicznej farsy, za którą kryją się machinacje Szatana. W teologicznej wykładni Benjamina alegoryk wikła się w grzech pierworodny, zdradzając „,świat gwoli wiedzy”23, zawierza bowiem łudzącej poznaniem mocy języka.

Rozprawa o dramacie żałobnym nawiązuje wprost do wczesnego traktatu O języku w ogóle i o języku człowieka, gdzie czytamy:

Wiedza o dobru i złu porzuca imię, stanowi poznanie z zewnątrz, niestwórcze naśladownictwo stwórczego słowa. W tym poznaniu imię wykracza poza siebie: Upadek jest chwilą narodzin ludzkiego słowa, w którym imię nie żyło już nieskalane [...]. Słowo jako komunikujące w sposób zewnętrzny, jawnie niebezpośrednie słowo, będące parodią jawnie bezpośredniego, stwórczego słowa Boga, oraz upadek błogiego, Adamowego ducha językowego, usytuowanego między nimi. Albowiem istnieje zasadnicza tożsamość słowa, które po kuszeniu przez węża poznaje dobro i zło, i słowa, które komunikuje w sposób zewnętrzny. Poznanie

${ }^{23}$ Benjamin, Źródło dramatu żałobnego, 201. 
rzeczy opiera się na imieniu, poznanie dobra i zła jest w głębokim sensie, $\mathrm{w}$ jakim posługiwał się tym słowem Kierkegaard, gadaniną ${ }^{24}$.

Alegoryk zwiedziony pseudokreatywnością swojego języka ulega $\mathrm{W}$ istocie pokusie satanicznego popędu wiedzy - "otchłani bezdennie głębokiego namysłu”: „Popęd w postaci wiedzy każe iść w dół, w otchłanną pustkę zła, by tam upewnić się co do nieskończoności. Jest to też jednak otchłań bezdennie głębokiego namysłu (Tiefsinn). Danych, którym ten namysł rozporządza, nie sposób wpisać w filozoficzne konstelacje" $^{\prime 25}$.

Bezdenny namysł $\mathrm{w}$ teologicznej wizji Benjamina jest rezultatem utraty rajskiego języka imion, objawia się on w umyśle alegoryka jako archetypowe pragnienie restytucji tego języka przy użyciu środków alegorycznych. Jego żałość płynie z niemocy nazywania i z niemoty samej natury, która nie może wybrzmieć właściwym imieniem. W naszej psychofilozoficznej wykładni niema natura ogarnięta smutkiem z powodu niemożności bycia nazwaną oznacza traumatyczne cierpienia przeszłości, które nie mogą znaleźć wyrazu w abstrakcyjnym języku i wywołują $\mathrm{w}$ alegorycznym podmiocie kompulsywną potrzebę artykulacji niewyrażalnego. W kontekście samego dramatu żałobnego Benjamin wskazuje jeszcze jedno źródło tej potrzeby.

Średniowiecze przechowuje antyczne wyobrażenia ciał bogów, ale już nie w formie triumfalnej i pogodnej, ale jako uosobienie demonicznej, budzącej grozę, pogańskiej mocy. Jak pisze Benjamin: „[...] warunkiem alegorycznej przemiany panteonu $\mathrm{w}$ świat magicznych stworzeń o charakterze pojęciowym jest to, że postacie obumieraja a pojęcia się wyabstrahowują"26. Przykładem jest wyobrażenie Amora jako demona nieobyczajności oraz innych mitycznych postaci jak choćby centaura, fauna, harpii, które przeobrażają się w alegoryczne figury piekła chrześcijańskiego. Alegoreza jest tutaj środkiem transformacji antycznego mitu w „fizyczność, na której ciąży wina" 27. Uosobieniem złej, obciążonej winą fizyczności staje się Szatan, który w głębiach alegorycznej żałości „[...] może wychynąć wprost z ziemskiej otchłani i drwiąc z wszelkiego emblematycznego sztafażu, ukazać się oczom alegoryka" 28 .

Szatan to materia, fizyczność obciążona wina, czyli natura podwójnie oniemiała brakiem Adamowego języka imion oraz gadaniną arbitralnych języków rozproszonych po katastrofie Wieży Babel. Przyrododzieje wyłaniające się w dobie baroku ograbiają naturę nawet z symbolicznej

\footnotetext{
${ }^{24}$ Tegoż, O języku w ogóle i o języku człowieka, 13-14.

${ }^{25}$ Tegoż, Źródło dramatu żałobnego, 312.

26 Tamże, 305.

27 Tamże, 306.

28 Tamże, 307.
} 
apoteozy antyku (przyroda symbolizowana przez olimpijskich bogów) i średniowiecza (przyroda jako symbol doskonałości Stwórcy). Ze świata wyparowują resztki obiektywnego znaczenia, istnieje tylko ogarnięta żałościa, wybujała subiektywność, która konfrontuje się z bezduszną materią. Barokowa wizja przybiera więc postać gnostyckiego dualizmu. Upadła dusza alegoryka, który próbuje odzyskać metafizyczny sens świata, grzęźnie w demonicznej, nicującej wszystko materii. Diabeł reprezentuje materię całkowicie oczyszczoną z suwerennego znaczenia i w ten sposób wyraża świadomość jej „,tartarycznej natury"29. Objawem tej świadomości jest sataniczny, szyderczy śmiech, z którym prędzej czy później konfrontuje się alegoryk. „Akurat przez śmiech materia w arcyekscentrycznym kamuflażu, z przesadą i egzaltacja, nabiera cech duchowych. Staje się tak duchowa, że daleko przewyższa język. Chce wznieść się wyżej, aż na koniec wybucha hałaśliwym śmiechem"30.

Zagubiony w kontemplacyjnej alegorezie, melancholijny duch odnajduje ostatecznie $\mathrm{w}$ materii własne odzwierciedlenie. Niczym w lustrze rozpoznaje swoją nicość, a echem tego rozpoznania staje się słyszalny niejako z zewnątrz śmiech tego, co zostało skazane na niemotę. „To, co czysto materialne, i to, co absolutnie duchowe, są biegunami dziedziny Szatana, a świadomość ich kuglarską syntezą, małpującą syntezę autentyczna, syntezę życia" ${ }^{\prime \prime}$.

Alegoryk zstępuje do piekła, w którym niedialektycznie zabsolutyzowana podmiotowość wiedziona pokusą wiedzy zderza się z materią. Zamiast obiecanej dynamicznej syntezy tworzy się tutaj pasywna przestrzeń skrajnego wyobcowania świadomości od materii, która nie prowadzi do żadnego pojednania. Doświadczenie alegoryczne dociera jednak do granicy, na której z jednej strony ukazuje się czyste zło (a ściślej: wiedza o złu, czyli o niebycie - zgodnie z doktryną św. Augustyna), a z drugiej strony odsłania się przestrzeń ocalenia: „Utkwione na koniec w barokowych stygmatach śmierci spojrzenie alegoryczne odwraca się raptownie: teraz dopiero zatacza największy łuk wstecz i zbawia [...]. Bo również czas piekła zostaje zsekularyzowany w przestrzeni, a ów świat, który wydawał się na pastwę głębokiego ducha szatana i nie stronił od zdrady, jest światem Bożym. W świecie Bożym rodzi się alegoryk" ${ }^{\prime \prime 2}$. W rezultacie przeskoku ku Zmartwychwstaniu alegoryk traci wszystko, przedmioty poddawane jego alegorycznym wysiłkom wypowiadają mu posłuszeństwo, zamiast jednak zanieść się szatańskim śmiechem, wykonują zwrot ku ocaleniu. Alegoryczna dialektyka kończy się u Benjamina teologicznym motywem cudownej, mistycznej przemiany.

\footnotetext{
29 Tamże.

30 Tamże, 308.

31 Tamże, 312.

32 Tamże, 314-315.
} 
W perspektywie finału alegoria oznaczająca "coś innego niż to, czym jest" ${ }^{\prime 33}$, okazuje się kwintesencją zła, natomiast alegoreza stanowiąca horyzontalny dryf znaków staje się jedynym skutecznym środkiem, który niszczy iluzję symbolicznego ładu i prowadzi ogarnięty żałością podmiot $\mathrm{w}$ bezdenny szyb głębokiego namysłu, gdzie może wydarzyć się misterium Zmartwychwstania.

\section{Przeskok ku Zmartwychwstaniu}

Finałowa epifania dokonująca się za pośrednictwem zewnętrznej interwencji cudu stanowi znak rozpoznawczy, teologiczne credo wielu barokowych dramatów ${ }^{34}$, choć w wykładni Benjamina można odnaleźć bardziej filozoficzny kontekst dla tego motywu. Gwałtowne zatrzymanie ruchu alegorycznej intencji oznacza bowiem również bliskość prawdy, a - jak pisze Benjamin w swojej przedmowie - „Prawda jest śmiercią intencji [...]. Struktura prawdy wymaga przeto bytu, który ze względu na swoją nieintencjonalność byłby taki jak prosty byt rzeczy"35. Jeśli odczytamy finałowy rozbłysk światła transcendencji zgodnie z cytowanym powyżej ujęciem prawdy, będziemy mogli pokusić się o bardziej świecką interpretację.

Zabsolutyzowana subiektywność alegoryczna, docierając do granicy swojej intencjonalności, napotykałaby wówczas rzeczopodobny byt prawdy, czyli utracony (wyparty) obiekt, który napędzał całą dynamikę żałości i alegorezy. Obiekt ten w naszej interpretacji stanowiłby najgłębszy, niedostępny dla języka i świadomości wymiar podmiotu, czyli najważniejszą sprężynę napędową pragnienia życia - życia pełnego i wolnego od jarzma narzucanego przez katastroficzną przyrodohistorię. Transcendentne światło Zmartwychwstania, ku któremu w końcowej partii rozprawy Benjamina przeskakuje ostatnia alegoryczna intencja, można byłoby w tej perspektywie odczytać jako moment rozbłysku czy manifestacji pragnienia przepełnionego nadzieją na ocalenie, którego alegorycznym obrazem jest uniwersum rajskich imion. Źródłem tego pragnienia byłaby energia niewyartykułowanych cierpień przeszłości, które w cudowny właśnie, czyli niespowodowany przez sam podmiot, sposób przekształcają się w nieznający lęku nadmiar życia - w swoistą apokatastasis upadłych momentów życia w świetle utopijnego, jeszcze nieistniejącego pojednania.

Alegoryczny sposób widzenia stanowi konsekwencję żałości, jest kompulsywną reakcją obronną melancholika, który utracił wszelkie

\footnotetext{
33 Tamże, 316.

34 Tamże, 318.

35 Tamże, 18, 19.
} 
złudzenia i nadzieje na odnalezienie całościowego sensu w uniwersum przyrododziejów. Moment skrajnego zanurzenia w otchłani otwierającej się po zniszczeniu fasady iluzorycznego ładu i celowości dziejów uruchamia proces artykulacji stłumionych cierpień przeszłości, które nie znalazły dotąd odpowiedniego środka wyrazu. Wyzwolenie niemych, wypartych z panującego porządku symbolicznego impulsów skargi prowadzi do transformacji apokaliptycznej wizji dziejów w rozbłysk mesjańskiej nadziei na ocalenie.

W tym kontekście nasuwa się pytanie: co w takim razie odsłania się melancholijnemu alegorykowi, który doświadczył transfiguracji „zakrzepłej", wyjałowionej ze znaczenia Naturgeschichte? Benjamin nie odpowiada wprost na to pytanie, nie opisuje też, w jaki sposób mesjańska iskra nadziei rozbłyskująca na dnie żałości może rozpalić się i ogarnąć swym płomieniem całą ludzkość. Niewątpliwie mamy tutaj do czynienia z profetyczno-utopijnym wątkiem jego historiozofii. Nie będziemy go dalej analizować, ponieważ wymagałoby to odniesienia do innych dzieł podejmujących tę problematykę.

Na pierwszy rzut oka alegoryczna zawartość prawdy (Wahrheitsgehalt) dramatu żałobnego podąża za archetypowym modelem chrześcijańskiej eschatologii: ofiarniczą śmiercią Chrystusa na krzyżu. Zmartwychwstanie stanowi ogniwo pośrednie między skończonością upadłego świata, reprezentowaną przez Jego śmierć, a wiecznym życiem w królestwie Zbawienia. Jednakże nie należy przypisywać samemu Benjaminowi chrześcijańskiej wizji, tym bardziej że najsilniejsze teologiczne impulsy tkwiące za jego fascynacją dramatem żałobnym wywodzą się z kabalistycznych motywów, nad którymi pracował wcześniej w pracach O języku w ogóle i języku człowieka, Fragmencie teologiczno-politycznym, oraz z jego samodzielnych pomysłów, które w późniejszej fazie twórczości nabrały wymiaru materialistycznego.

\section{Podsumowanie - czym jest podmiot alegoryczny?}

Na koniec zastanówmy się, jaki rodzaj podmiotu wyłania się w alegorycznym uniwersum dramatu żałobnego. Podmiot oddany alegorezie niewątpliwie redefiniuje swój stosunek do cielesności. Jego zwrot ku stworzeniu, ku nagiemu życiu, odsłania przed nim przestrzeń symptomów melancholijnych: wyobcowania z ciała, erupcji tłumionych uczuć, nadaktywności językowej, w której zanika związek między znakiem a całkowicie dowolnym znaczeniem. Zdysocjowana percepcja nie zostaje tutaj poddana symbolizacji charakterystycznej dla pracy żałoby. Podmiot dosłownie zanika w swoich symptomach, zanurza się $\mathrm{w}$ prawdzie wypartego cierpienia, które rozrywa spoiny języka, zamienia go $\mathrm{w}$ lament, w ostentacyjną nadekspresję lub w ornamentalne pustosło- 
wie. Cielesność zostaje opanowana bez reszty tanatycznym popędem, o czym świadczy ciągła repetytywność objawów, tendencja do mortyfikacji obiektów i ciała. Niemal każdy wątek dramatu żałobnego ociera się o śmierć, a alegoryczny język upodabnia się do horyzontalnego przepływu znaków, który Freud w swoich analizach marzenia sennego ochrzcił mianem mechanizmu przesunięcia (Verschiebung), a Lacan pracą metonimii. Alegorie nie łączą się ze ściśle określonym znaczeniem, odsyłają jedynie do innych alegorii, znaków, tworząc nieustanny semiotyczny dryf pozbawiony jakiegokolwiek celu. Stawką wydaje się tutaj jednak utopia nowego życia, a nie destytucja podmiotowości, jak u Lacana. Rozkład idiomu językowego, rozproszenie świadomości staje się raczej ceną którą podmiot musi zapłacić za odzyskanie nadziei na pełniejsze, pojednane życie, za przekształcenie cierpienia w pragnienie nowej witalności. U Benjamina to utopijne, witalizujące marzenie jest anamnetycznym echem rajskich imion, które w późniejszej twórczości będzie lokalizował w pamięci mimowolnej jako odnaleziony raj mimetycznych doświadczeń dzieciństwa ${ }^{36}$.

Alegoryk pozostaje nadal męczennikiem, ale w przeciwieństwie do niego zajmuje aktywną postawę wobec wewnętrznej i zewnętrznej katastrofy oraz stanu anomii. W tym sensie jest podmiotem postapokaliptycznym, instalującym się $\mathrm{w}$ świecie zrujnowanym, pozbawionym jakichkolwiek metafizycznych, substancjalnych zabezpieczeń. Utrata centrum, trwałej struktury symbolicznej powoduje, że zagłębia się on $\mathrm{w}$ odarte ze znaczenia wnętrze materialnego świata i tajemnicze, nienazywalne przestrzenie własnej cielesności. Jego język zalewają niekomunikacyjne (rzeczowe, jak pisze Benjamin) elementy języka odzwierciedlające się $\mathrm{w}$ pretensjonalnym słowotwórstwie, w wykrzyknikach, zawodzeniach, pauzach i przerywanej rytmice wypowiedzi. Język dramatu żałobnego stanowi, jak pisze Benjamin w innym miejscu, stadium przejściowe,

[...] drogę wiodącą od dźwięku naturalnego poprzez skargę do muzyki. W dramacie żałobnym dźwięk rozkłada się na sposób symfoniczny i w tym należy upatrywać zarówno muzycznej zasady języka tego dramatu, jak i dramatycznej zasady jego rozdwojenia i rozszczepienia na postacie. [...] Gra sprzeczności między dźwiękiem a znaczeniem pozostaje dla dramatu żałobnego czymś widmowym, przerażającym, jego opętana przez język natura pada ofiarą nieskończonego uczucia ${ }^{37}$.

36 Por. Michalski, Antropologia mimesis.

${ }_{37}$ Walter Benjamin, Znaczenie jezzyka w barokowym dramacie żałobnym i tragedii, w: tegoż, Konstelacje, przeł. A. Lipszyc, A. Wołkowicz (Kraków: Wydawnictwo Uniwersytetu Jagiellońskiego, 2012), 20, 21. 
Rozpad konwencjonalnego języka ożywia rany zakryte przez symboliczne inskrypcje wpisane w ludzką cielesność i psychikę. Emblematem upadku autorytarnej mocy konwencjonalnego języka jest powtarzający się motyw korony spadającej z głowy suwerena. Hegemoniczne znaczące, które organizuje język komunikacji, osuwa się z uprzywilejowanej, centralnej pozycji jak królewska korona, pozostawiając nagi acefaliczny podmiot, zdany na kipiel bezsłowia pieniących się fal nieświadomości. W ten sposób tworzy się niejako wtórna trauma wyzwalająca ukryte dotąd popędy. Do głosu dochodzą idiosynkratyczne impulsy, chaotyczne, niekomunikacyjne i polisemiczne substraty mowy. Alegoryk nie oddaje się im jednak bezwolnie, nie składa siebie w ofierze, lecz próbuje na nowo zrekonfigurować rozproszone fragmenty uniwersum swojego świata, staje się absolutnym suwerenem znaczenia, mimo że próby ukonstytuowania nowego, spójnego ładu kończą się zawsze fiaskiem. Arbitralna alegoreza działa w jego przypadku jak rodzaj szczepionki, podmiot świadomie infekuje się zarazkami rozkładu (produktami ubocznymi procesów zachodzących w sferze przyrododziejów), aby zwiększyć swoją odporność na nie. Ochrona przed zalewem psychotycznych stanów, które mogłyby całkowicie zaanektować podmiot, wymaga od niego decyzji, która z chaosu rozpadającej się mowy buduje nowe łańcuchy sygnifikantów. Za Lacanem możemy nazwać ten akt herezją (od gr. haeresis - akt wyboru), a podmiot szukający ratunku w samowolnym budowaniu nowych struktur znaczenia, a tym samym w konstruowaniu na na nowo własnej subiektywności - podmiotem heretyckim. W świetle tej interpretacji jaźń alegoryka staje się prototypem struktury ego, które uwalnia się od władzy traumatyzującego i legitymizującego edypalny porządek języka kultury i społecznej komunikacji.

Ważna $\mathrm{w}$ tej przemianie podmiotowości jest erupcyjna siła samego dźwięku, nośnika wypartych urazów, ponieważ przekład uczucia na język dokonuje się tutaj bez pośrednictwa wyobraźni, imaginacyjnych formacji, które deformują i hamują bezpośrednią ekspresję cierpienia, poddając jego skargę władzy obronnych mechanizmów ego. Męczennik dociera do tego etapu, jednak nie podejmuje „heretycznej” decyzji i dlatego nie potrafi wynieść cierpienia do poziomu reprezentacji. W finale popada $\mathrm{w}$ psychozę, w stan dysocjacji, która zamienia jego cielesność w fantazmatyczne, pokawałkowane ciało, a język w chaos artykulacji. Natomiast alegoryk aktem arbitralnej decyzji sam ustanawia siebie jako władczego onomaturga, stabilizuje znaczenie, nadaje mu granice, unikając gwałtownego wtargnięcia nieświadomości w przestrzeń mowy. Staje się postapokaliptycznym suwerenem $\mathrm{w}$ uniwersum symbolicznej anomii, mistrzem gier językowych, które $\mathrm{w}$ finale prowadzą do transformacji zahamowanej, straumatyzowanej energii cierpienia w strumień ocalonego życia. 
We Fragmencie teologiczno-politycznym Benjamin zrównuje szczęście ze świecką ekspresją mesjańskiego ocalenia. Szczęście jako przebudzenie życia pełnego (a nie nagiego w sensie biologicznych popędów nastawionych na przetrwanie) dokonuje się według niego w momencie upadku w przemijalność, kiedy zwierciadło zanikającej i odradzającej się natury przestaje dawać oparcie dla iluzorycznego pragnienia trwałości i pozwala doświadczyć chwilowego rozbłysku pełni jako rewersu tego, co przemijalne. To eudajmoniczne doświadczenie niepozbawione jest jednak ironii, ponieważ zakłada arbitralną grę znakami, z której czerpie witalizujący przypływ energii. Szczęście jako przeczucie wieczności życia to zarazem dogłębne doświadczenie jego przemijalności. „Albowiem w szczęściu wszystko, co ziemskie, zdąża do swego upadku, a tylko w szczęściu dane jest mu go odnaleźć". W ten sposób powstaje restitutio doczesna, „[...] która prowadzi ku wieczności upadku, a rytmem tej wiecznie przemijającej doczesności [...], rytmem mesjańskiej natury jest szczęście. Albowiem z perspektywy swego wiecznego i całkowitego przemijania natura jest mesjańska" ${ }^{38}$.

Podmiotowość alegoryczna w punkcie wyjścia przypomina współczesny podmiot, jest urzeczowiona, sfragmentaryzowana i zdepersonalizowana, pozbawiona stabilnego centrum, przez co staje się podatna na kuszące kompensacje przybierające $\mathrm{z}$ jednej strony formę dominacji, megalomanii, kontroli, a z drugiej strony formę izolacji, pasywności oraz iluzji nieśmiertelności. W przełomowym, finałowym stadium staje się zaś podmiotowością postapokaliptyczną zdolną do autokreacji $\mathrm{w}$ świecie pozbawionym trwałego sensu, która wykorzystuje wyparte traumatyczne cierpienia do budowy nowego porządku symbolicznego. Co może zyskać dzięki temu? Epifania ironicznego szczęścia jest dla niej jedynie czymś momentalnym, tymczasowym, czymś, co mimo wszystko daje jej na tyle dużo witalizującego elan vital, aby mogła po prostu żyć dalej w upadłym świecie. To dalsze życie nie jest jednak tylko aktem afirmacji, stoickiego pogodzenia się z naturą przemijalności. Daje ono bowiem rebeliancka, nadmiarową energię, która uwalnia od opresyjnej mocy symbolicznego porządku i pozwala oddać sprawiedliwość przeszłym cierpieniom. Ostatecznie to sama żałość staje się źródłem ocalenia: „W dramacie żałobnym smutek sam siebie przyzywa, lecz także sam siebie zbawia" ${ }^{\prime 39}$.

${ }^{38}$ Walter Benjamin, Fragment teologiczno-polityczny, w: tegoż, Konstelacje, tłum. A. Lipszyc, A. Wołkowicz (Kraków: Wydawnictwo Uniwersytetu Jagiellońskiego, 2012), 95, 96.

${ }^{39}$ Tegoż, Znaczenie jezzyka w barokowym dramacie, 21. 


\section{Bibliografia}

Benjamin Walter. 2013. Źródło dramatu żałobnego w Niemczech, przeł. A. Kopacki. Warszawa: Wydawnictwo Sic!

Benjamin Walter. 2012. O języku w ogóle i o języku człowieka. W: Walter Benjamin, Konstelacje, przeł. A. Lipszyc, A. Wołkowicz. Kraków: Wydawnictwo Uniwersytetu Jagiellońskiego, 1-18.

Benjamin Walter. 2012. Znaczenie języka w barokowym dramacie żałobnym i tragedii. W: Walter Benjamin, Konstelacje, przeł. A. Lipszyc, A. Wołkowicz. Kraków: Wydawnictwo Uniwersytetu Jagiellońskiego, 19-22.

Benjamin Walter. 2012. Fragment teologiczno-polityczny. W: Walter Benjamin, Konstelacje, przeł. A. Lipszyc, A. Wołkowicz. Kraków: Wydawnictwo Uniwersytetu Jagiellońskiego, 95-96.

Benjamin Walter. 2012. Los i charakter. W: Walter Benjamin, Konstelacje, przeł. A. Lipszyc, A. Wołkowicz. Kraków: Wydawnictwo Uniwersytetu Jagiellońskiego, 61-68.

Blumenberg Hans. 2019. Prawowitość epoki nowożytnej, przeł. T. Zatorski. Warszawa: PWN.

Butler Judith. 2004. Violence, mourning, politics. W: Judith Butler, Precarious life. The powers of mourning and violence. London-New York: Verso, 19-49.

Lipszyc Adam. 2012. Sprawiedliwość na końcu języka. Kraków: Universitas. Lukács György. 1968. Teoria powieści, przeł. J. Goślicki. Warszawa: PIW.

Michalski Rafał. 2008. Antropologia mimesis. Studium myśli Waltera Benjamina $i$ Theodora W. Adorna. Zła Wieś: Wydawnictwo Rolewski.

Michalski Rafał. 2019. „Melancholia i katastrofa w barokowym dramacie żałobnym". Ruch Filozoficzny, 2: 45-66.

\section{Streszczenie}

Artykuł poddaje analizie koncepcję alegorii Waltera Benjamina zawartą $\mathrm{w}$ jego rozprawie The Origin of German Tragic Drama. Główny nacisk zostaje położony na przedstawienie alegorezy (alegorycznej interpretacji znaków) jako reakcji obronnej podmiotu, który znalazł się w stanie anomii i kryzysu tożsamości. Alegoria przeciwstawiona symbolowi odzwierciedla charakterystyczne dla baroku przeobrażenie historii Zbawienia $\mathrm{w}$ pozbawione celu i odniesienia do absolutu przyrododzieje (Naturgeschichte). W ten sposób staje się ona idealnym środkiem wyrazu dla gry żałości, która wyprowadza melancholijny podmiot ze stanu kryzysu i pomaga mu ukonstytuować nowe uniwersum symboliczne. Artykuł ukazuje genezę barokowej alegorii, jej kontekst teologiczny oraz implikacje filozoficzne.

Słowa kluczowe: alegoria, symbol, gra żałości, Walter Benjamin, mesjańska nadzieja, przyrododzieje 


\section{Summary}

\section{The Play of Mourning - Allegory in Baroque Tragic Drama}

The article analyses the concept of allegory included in Walter Benjamin's dissertation The Origin of German Tragic Drama. The main emphasis is placed on the presentation of the allegorical interpretation of signs as a defensive reaction of the subject who is in a state of anomy and identity crisis. The allegory contrasted with the symbol reflects the baroque transformation of salvation history into the Naturgeschichte, the goal-less and deprived of any reference to absolute natural history. In this way, it becomes ideal means of expression for the game of mourning, which brings the melancholic subject out of crisis and helps him to form a new symbolic universe. The article shows the genesis of baroque allegory, its theological context and philosophical implications.

Keywords: allegory, symbol, mourning play, Walter Benjamin, messianic hope, natural history 